\title{
A new index in the follow-up of arrhythmia of Coronavirus Disease-2019 (COVID-19) patients receiving Hydroxychloroquine and Azithromycin therapy; index of cardiac electrophysiological balance
}

\section{Hidroksiklorokin ve Azitromisin tedavisi alan Koronavirüs Hastalığı-2019 (COVID-19) hastalarının aritmi takibinde yeni bir endeks; kardiyak elektrofizyolojik denge endeksi}

İsa Ardlahanlı1, Onur Akhan¹, Ramazan Aslan¹, Mehmet Çelik², Okan Akyüiz ${ }^{3}$

Department of Cardiology, Bilecik Training and Education Hospital, Bilecik, Turkey

${ }^{2}$ Department of Endocrinology and Metabolism, Trakya University Faculty of Medicine, Edirne, Turkey

Department of Nephrology, Istanbul Kartal Dr. Lütfi Kırdar City Hospital, Istanbul, Turkey

Corresponding author: Isa Ardahanl, MD, Department of Cardiology, Bilecik Training and Education Hospital, Bilecik, Turkey

E-mail: isaardahanli@gmail.com

Received/Accepted: January 28, 2021 / February 05, 2021

Conflict of interest: There is not a conflict of interest.

\section{SUMMARY}

Objective: Index of cardiac electrophysiological balance (iCEB) is a relatively new electrocardiographic (ECG) parameter that shows the balance between ventricular depolarization and repolarization, thus providing more information than other conventional ECG parameters such as QT and corrected QT (cQT) intervals. This study aimed to evaluate the condition of iCEB with the treatment of hydroxychloroquine and azithromycin used in COVID-19 patients.

Method: The study was designed as cross-sectional and descriptive. Sixty three (52 male, $28.4 \pm 10.7$ years) COVID-19 patients with mild symptoms who received hydroxychloroquine and azithromycin treatment between 30 March and 30 June 2020 were included in the study. iCEB and corrected iCEB (iCEBc) values were calculated by dividing the respective QT and cQT intervals by the QRS duration.

Results: In the study group, the mean PR, QRS, QT and cQT intervals were similar between groups. While heart rate was significantly higher before treatment, iCEB and iCEBc increased significantly after treatment.

Conclusions: Our study did not observe a significant difference in QT and cQT intervals with hydroxychloroquine and azithromycin treatment in COVID-19. Still, there was a significant increase in the $\mathrm{iCEB}$ and $\mathrm{iCEBc}$. We believe that the cardiac electrophysiological balance index can be used to monitor arrhythmias in patients undergoing short-term treatment at COVID -19.

Keywords: COVID-19, SARS-CoV-2, arrhythmia, QT interval, index of cardiac electrophysiological balance.

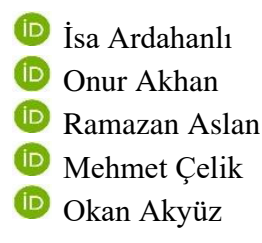

ORCID IDs of the authors: I.A. 0000-0002-9309-803X O.A. 0000-0003-4440-9599 R.A. 0000-0002-1255-7880 M.Ç. 0000-0001-7364-370X O.A. 0000-0003-2460-9577 
ÖZET

Amaç: Kardiyak elektrofizyolojik denge indeksi (iCEB), ventriküler depolarizasyon ve repolarizasyon arasındaki dengeyi gösteren ve böylece QT ve düzeltilmiş QT (cQT) aralıkları gibi diğer geleneksel EKG parametrelerinden daha fazla bilgi sağlayan nispeten yeni bir elektrokardiyografik (EKG) parametredir. Bu çalışma COVID-19 hastalarında kullanılan hidroksiklorokin ve azitromisin tedavisi ile iCEB'nin durumunu değerlendirmeyi amaçladı.

Yöntem: 30 Mart - 30 Haziran 2020 tarihleri arasında hidroksiklorokin ve azitromisin tedavisi alan, hafif semptomlu 63 (52 erkek, $28.4 \pm 10.7$ yll) COVID-19 hasta çalışmaya dahil edildi. iCEB ve düzeltilmiş iCEB (iCEBc) değerleri, ilgili QT ve cQT aralıklarının QRS süresine bölünmesiyle hesaplandı.

Bulgular: Çalışma grubunda ortalama PR, QRS, QT ve cQT aralıkları gruplar arasında benzerdi. Tedaviden önce kalp atış hızı önemli ölçüde yükselirken, iCEB ve iCEBc tedaviden sonra önemli ölçüde arttı.

Sonuç: Çalışmamızda COVID-19'da hidroksiklorokin ve azitromisin tedavisi ile QT ve cQT aralıklarında anlamlı bir fark gözlenmedi. Yine de, iCEB ve iCEBc'de önemli bir artı̧ oldu. COVID-19'da kısa süreli tedavi gören hastalarda aritmileri izlemek için kardiyak elektrofizyolojik denge indeksinin kullanılabileceğine inanıyoruz.

Anahtar sözcükler: COVID-19, SARS-CoV-2, aritmi, QT aralı̆̆ı, kardiyak elektrofizyolojik denge indeksi.

\section{INTRODUCTION}

2019 Nowel Coronavirus Disease (COVID-19) is a viral disease that was first detected as a result of research conducted in a group of patients who developed respiratory symptoms (fever, shortness of breath, cough) in China in late December ${ }^{1,2}$. On January 30, 2020, the World Health Organization (WHO) declared COVID-19 an international public health emergency, and on March 11, 2020, it was said a pandemic ${ }^{3}$. Since then, the virus has spread internationally, infected approximately 95 million people, and resulted in more than 2 million deaths ${ }^{4}$. This situation seriously affected social life and economies. Vaccine finding studies are ongoing, yet its effectiveness has been thoroughly proven and is not used at the social level. Although there are no robust data to support any specific therapy, several pharmacological agents have been proposed in the hope of reducing disease-related morbidity and mortality. In recent studies, hydroxychloroquine, azithromycin and favipiravir treatment stands out ${ }^{5}$.

In data supporting the use of hydroxychloroquine in the treatment of COVID-19, it has been found that it has an in vitro effect against the virus. However, these are limited, non-comparative clinical studies ${ }^{6-9}$. Azithromycin is an antibiotic that effectively treats bacterial pneumonia and is thought to have antiviral activity ${ }^{10,11}$. Both drugs prolong QT by blocking cardiac potassium channels and have the potential for ventricular arrhythmia. In particular, prolonging QT has been shown in previous studies to cause TdP, but its absolute risk is low and safe in clinical practice 12,13 . The data are not sufficient to obtain reliable results on drug combinations used in the treatment of COVID-19. Combining multiple proarrhythmic drugs significantly increases the risk of QT prolongation ${ }^{14}$. There have been studies of this combination drug in QT distance in previous studies, and it has been shown that short-term use does not lead to significant QT prolongation ${ }^{15}$. There were no studies in the literature regarding the assessment of ventricular arrhythmia risk in COVID-19 patients who received short-term combination therapy using cardiac electrophysiological balance index.

The cardiac electrophysiological balance index (iCEB) is a new ECG parameter that can be predicted by dividing the QT by QRS (QT/QRS) and predicting ventricular arrhythmogenesis ${ }^{16,17}$. It is suggested that ICP is a marker equivalent to $\lambda(\lambda$ $=$ effective refractory period $[E R P] \times$ conduction rate $[\mathrm{CV}])$ and represents the balance between depolarization and repolarization ${ }^{16}$. This respect can give better information about the risk of proarrhythmia than the QT interval, which only shows repolarization ${ }^{17}$. Increased iCEB was associated with $\mathrm{TdP}$, while decreased values were shown to be related to non-Torsade VT / VF ${ }^{16}$.

Our aim in the study was to compare the iCEBs of individuals with asymptomatic or mild to moderate symptoms of SARS-CoV-2 infection by evaluating ECGs before and after hydroxychloroquine + azithromycin treatment.

\section{MATERIAL AND METHODS}

This study was carried out single-center and retrospectively. Hospital records of 63 patients diagnosed with COVID-19 (11 female, 52 male, average age $28.4 \pm 10.7$ years) who had symptoms such as mild fever and cough between 30 March 2020 and 30 June 2020 in our institution were retrospectively scanned. The ECGs of the patients were evaluated at the beginning and after the treatment. Lung computed tomography (CT) 
results of all patients were examined. It was observed that they formed mostly organized pneumonia patterns, predominantly peripheral frost-glass-like opacities, mostly bilateral and multilobar nodular frost-glass-like opacities. Nasopharyngeal and pharyngeal swabs were taken from all participants and sent to the microbiology laboratory for Polymerase Chain Reaction (PCR) testing. PCR and lung CT were used for the diagnosis of COVID-19. Demographic and clinical features and ECG recordings were taken from medical records.

Physical examination was not performed in patients in the study group unless there were an indication and clinical condition deterioration to reduce the risk of transmission to physicians and other healthcare workers. Anthropometric measurements of all patients were taught by health workers to minimize the risk of transmission. Study participants had no history of significant clinical problems. In addition to symptomatic treatment, all patients received hydroxychloroquine $200 \mathrm{mg} 2 \mathrm{x} 1$ (p.o) maintenance after $200 \mathrm{mg} 2 \times 2$ loading dose, and azithromycin $500 \mathrm{mg} \mathrm{1x1}$ (p.o) treatment was started. 12-lead superficial ECG was obtained from all participants before and during the 5-day standard treatment. Echocardiographic evaluation was performed on patients who defined cardiac complaints and considered cardiac complications. Other than that, it was not done because of the risk of contamination.

\section{Exclusion criteria:}

- Those who are followed in intensive care units, whose general condition is impaired or intubated.

- Those with a history of heart failure and coronary artery disease.

- Mid-severe valvular heart disease.

- Chronic renal failure (glomerular filtration rate of $<60 \mathrm{ml} / \mathrm{min}$ ).

- Patients with a history of chronic obstructive pulmonary disease (COPD) (due to the possible effects of using inhaler treatments on ECG parameters)

- Patients with complete bundle branch blocks and U wave in ECG (The reason for excluding complete branch blocks was that the QT and QRS measurements could be misinterpreted).

- Endocrine disorders

- Electrolyte imbalance that may have arrhythmia potential (such as hypocalcemia, hypokalemia, hyperkalaemia and hypomagnesemia).

- Antiarrhythmic drug use history (such as beta-blockers, calcium antagonists, and amiodarone)

\section{Electrocardiographic evaluation}

ECG recorder (Nihon Kohden, Tokyo, Japan) was set at $25 \mathrm{~mm} / \mathrm{s}$ paper speed, and $10 \mathrm{~mm} / \mathrm{mV}$ voltage was used. An ECG device (Nihon Kohden, Tokyo, Japan) tuned to a speed of $25 \mathrm{~mm} / \mathrm{s}$, and 10 $\mathrm{mm} / \mathrm{mV}$ voltage was used for recording. ECG strips are scanned and digitalized, and digital recordings are analyzed on personal computers under $\mathrm{x} 300 \%$ magnification. PR, QRS, QT, and RR intervals were calculated manually from lead 2 . The distance from the beginning of the $\mathrm{Q}$ wave to the end of the $\mathrm{T}$ wave was determined as the QT interval and corrected using the Bazzet's formula: $\mathrm{cQT}=\mathrm{QT} \sqrt{ }(\mathrm{R}-\mathrm{R}$ interval $)$ according to the heart rate. Maximum QT (QTmax) and minimum QT (QTmin) durations were calculated by taking the longest and shortest QT intervals measured on the ECG.

QT / QRS ratio was used in the iCEB calculation, and cQT/QRS ratio was used in the analysis of the iCEBc. All ECGs were taken in regular breathing pattern and supine position for at least 10 minutes after rest. All ECG recordings were measured by two different cardiologists blinded by the study data to avoid inter-observer variability.

\section{Statistical analysis}

Statistical Package for the Social Sciences (SPSS) software (version 24.0; SPSS Inc., Chicago, IL, USA) was used to perform statistical analysis. Categorical variables were expressed as a percentage $(\%)$ and frequency, while continuous variables were presented as mean \pm standard deviation. Kolmogorov -Smirnov and ShapiroWilk tests were used for normality testing. A comparison between groups was made using Mann-Whitney $U$ or independent sample t-test according to data distribution. Chi-square test was used to evaluate the differences of categorical variables between groups. In the statistical analysis, p-value $<0.05$ was considered significant.

\section{RESULTS}

The average age of the study group was $28.4 \pm 10.7$ years. The ECG of all participants was a normal sinus rhythm. The anthropometric and demographic characteristics of the participants are shown in Table 1. 
Table 1: Baseline demographic and anthropometric findings of the study population

\begin{tabular}{|c|c|}
\hline Variable & Value \\
\hline Age, years $($ Mean \pm SD) & $28.4 \pm 10.7$ \\
\hline Gender (n, \% , Female/male) & $11(17.46 \%) / 52(82.54 \%)$ \\
\hline BMI, $\mathrm{kg} / \mathrm{m}^{2}$ & $23 \pm 2.2$ \\
\hline Systolic BP, mmHg & $112 \pm 7.5$ \\
\hline Diastolic BP, mmHg & $69 \pm 6.4$ \\
\hline LVEF \% & $63.2 \pm 4.43$ \\
\hline
\end{tabular}

BP: Blood pressure, LVEF: Left ventricular ejection fraction; BMI: Body mass index

Table 2: Electrocardiographic findings of the study groups.

\begin{tabular}{|l|l|l|l|}
\hline Variable & Pre-treatment $(\mathbf{n = 6 3})$ & Post-treatment $(\mathbf{n}=\mathbf{6 3})$ & $\mathbf{P}$ \\
\hline Heart rate, beats/min & $82.30 \pm 9.40$ & $75.48 \pm 11.13$ & $<\mathbf{0 . 0 0 1}$ \\
\hline PR (ms) & $143.05 \pm 10.30$ & $143.46 \pm 13.25$ & 0.846 \\
\hline RR (ms) & $740.79 \pm 34.59$ & $807.56 \pm 58.15$ & $<\mathbf{0 . 0 0 1}$ \\
\hline QT (ms) & $390.26 \pm 25.84$ & $397.12 \pm 18.86$ & 0.091 \\
\hline cQT (ms) & $430.04 \pm 35.99$ & $436.92 \pm 25.68$ & 0.220 \\
\hline QRS (ms) & $96.78 \pm 8.53$ & $94.06 \pm 12.56$ & 0.159 \\
\hline iCEB (QT/QRS) & $4.06 \pm 0.43$ & $4.29 \pm 0.58$ & $\mathbf{0 . 0 1 3}$ \\
\hline ICCEBc (cQT/QRS) & $4.47 \pm 0.54$ & $4.72 \pm 0.64$ & $\mathbf{0 . 0 2 3}$ \\
\hline
\end{tabular}

iCEB: Index of of cardiac electrophysiological balance, iCEBc: Index of cardiac electrophysiological balance with correction.

Table 2 shows the ECG findings of the study population before and after the hydroxychloroquine + azithromycin treatment. The PR interval, QRS time, QT, and cQT intervals were within the normal reference ranges and were similar among the groups. Mean HR was significantly lower after treatment compared to pretreatment $(82.3 \pm 9.4$ and $75.5 \pm 11.1$, respectively, $\mathrm{p}<0.001)$. In the $\mathrm{iCEB}$ and $\mathrm{iCEBc}$ evaluation, the post-treatment patient group had higher iCEB ( $4.29 \pm 0.58$ vs $4.06 \pm 0.43, p=0.013$ ) and $\mathrm{iCEBc}$ values $(4.72 \pm 0.64$ vs $4.47 \pm 0.54$, $\mathrm{p}=0.023$ ) than the pre-treatment group.

\section{DISCUSSION}

In our study results, while there was no significant change in QT distances in COVID-19 patients who were given hydroxychloroquine and azithromycin combination therapy for an average of 5 days, we observed significant increases in $\mathrm{ICEB}$ and iCEBc.

This study's main findings are that although QT and cQT intervals were not affected after short-term hydroxychloroquine and azithromycin treatment, the cardiac electrophysiological balance index increased after treatment. In this context, we have shown that the use of drugs that can prolong the QT interval applied in standard therapy in COVID-19 patients does not increase QT in short-term treatment but increases iCEB, which we think may be an important indicator in the balance between ventricular repolarization and depolarization. This is the first study to show that those receiving treatment for COVID-19 infection may need other parameters in ventricular arrhythmogenesis monitoring. 
The QT and cQT intervals represent the time for ventricular depolarization and repolarization on the ECG. Abnormally prolonged QT is associated with an increased risk of ventricular arrhythmia, especially TdP. Hydroxychloroquine and azithromycin are known to prolong QT and cQT intervals. Recently, the increased use of these drugs due to COVID-19 has brought forward the followup of possible arrhythmias. Especially for potential risk of TdP, QT and cQT intervals are generally used. However, as in our study (short-term treatment, without comorbid conditions and relatively young population), the absence of significant changes in QT intervals suggested that other electrocardiographic parameters could be used in the follow-up. In this context, we planned to evaluate $\mathrm{iCEB}$ and ciCEB, a relatively new biomarker.

Cardiac electrophysiological balance index (iCEB), the ratio of QT to QRS (QT / QRS) calculated from surface ECG, is a new and straightforward ECG signal that can predict ventricular arrhythmogenesis. In several previous studies, it has been shown that a relatively new ECG parameter such as iCEB may be more useful than the $\mathrm{T}$ peak-to-end (Tpe) interval and QT duration alone in predicting ventricular arrhythmic events ${ }^{16,17}$. Tp-e interval and Tp-e/QT ratio are parameters showing ventricular depolarization and its prolongation has been observed to increase the risk of arrhythmogenesis ${ }^{18,19}$. Lu et al. showed that iCEB is more useful than current biomarkers (i.e. transmural dispersion of T-wave and instability of the QT interval) in predicting VT/VF potential risks in their experimental study on rabbits ${ }^{16}$. Some studies have shown that iCEB has prognostic value in some diseases ${ }^{20-22}$.

A recent study by Cipriani A. et al. In 22 COVID19 patients, QT and cQT were prolonged in patients treated with hydroxychloroquine and azithromycin ${ }^{23}$. In our study, these did not change significantly with treatment. One of the possible reasons for this was that the number of patients was less than our study group. Another reason was that the study group's average age was higher than ours and the comorbid conditions were higher. Another study observed that patients taking hydroxychloroquine due to COVID-19 were at risk for QTc prolongation and more extensive changes in QT distances with the addition of azithromycin to treatment. The studies' common feature was the use of QT interval in the follow-up of the arrhythmia and that the iCEB was not evaluated. COVID-19 can cause fatal arrhythmias by doing myocardial damage, regardless of drugs. A recent report found that $16.7 \%$ of hospitalized COVID-19 patients and $44.4 \%$ of patients hospitalized in intensive care units had malignant arrhythmias. One of the risk factors that can increase malignant arrhythmia is the prolonged QT interval due to the change in ventricular repolarization ${ }^{24}$. In our study group, there were no patients with findings suggesting myocardial damage. For this reason, QT intervals may not have changed in our study.

This was the first study in the literature. In our study, we showed that in patients with COVID-19 without comorbid status, iCEB and iCEBc may be a better parameter in predicting ventricular arrhythmias in short-term treatment hydroxychloroquine and azithromycin. We think that this index's evaluation in this group of patients can predict arrhythmias earlier and affect the treatment strategy.

\section{CONCLUSION}

In our study results, we found that hydroxychloroquine and azithromycin used in the treatment of COVID-19 and known to have arrhythmic potential, increase the ICEB before affecting QT and cQT in short-term treatment. We think that this index can be used in the follow-up of arrhythmias in patients treated for COVID-19.

\section{LIMITATION}

The primary limitation of the study is that the number of patients is relatively low and singlecentered. Another limitation was that the patient population was relatively young. Finally, there was no commonly accepted reference range for iCEB values; however, Robins et al. Suggested a preliminary reference range between 3.14 and 5.35. This reference range can be verified or changed by future extensive and multi-participant studies.

\section{ETHICAL APPROVAL}

The Institutional Ethics Committee approved the protocol of the study, and this study follows the standard guidelines of the Declaration of Helsinki. The study was approved by the Ministry of Health of the Republic of Turkey and Bilecik Provincial Health Directorate received local ethics committee approval.

\section{CONFLICT OF INTEREST}

There is no conflict of interest in the study.

\section{PATIENTS' CONSENT}

Since it was designed as a retrospective study, the data were collected from the hospital archive after the Ethics Committee's approval.

\section{FINANCIAL SUPPORT}

No financial support was received for this study. 


\section{AUTHORS CONTRIBUTION}

IA, OA, and RA: conceived the study design, literature search, data collecting and recording, manuscript writing and revision. MC and OA: performed the statistical analysis, preparing tables and figures, language supervision.

\section{REFERENCES}

1. Lu R, Zhao X, Li J, Niu P, Yang B, Wu H, et al. Genomic characterisation and epidemiology of 2019 novel coronavirus: implications for virus origins and receptor binding. Lancet 2020;395(10224):565-574.

doi:10.1016/S0140-6736(20)30251-8.

2. WHO Novel Coronavirus (2019-nCoV) Situation Report - 121 January 2020. Available from https://www.who.int/docs/defaultsource/coronaviruse/situationreports/2020012 1-sitrep-1-2019 ncov.pdf?sfvrsn=20a99c10_4. (Accessed 28 Feb. 2020).

3. World Health Organization. WHO DirectorGeneral's opening remarks at the media briefing on COVID-19 - 11 March. Available from

URL: https://www.who.int/dg/speeches/detail/ who-director-general-s-opening-remarks-atthe-media-briefing-on-covid-19-11-march2020. (Accessed March 2020).

4. World Health Organization. WHO Coronavirus Disease (COVID-19) Dashboard, Data last updated: 2020/11/14, 3:32pm CET. (Accessed 18 Jan. 2021)

5. Ahmet Aktaş, Burak Tüzün, Rukiye Aslan, Koray Sayin \& Hilmi Ataseven (2020) New anti-viral drugs for the treatment of COVID-19 instead of favipiravir, Journal of Biomolecular Structure and Dynamics, DOI: 10.1080/07391102.2020.180 6112

6. Liu J, Cao R, Xu M, Wang X, Zhang H, Hu H, et al. Hydroxychloroquine, a less toxic derivative of chloroquine, is effective in inhibiting SARS-CoV-2 infection in vitro. Cell Discov. 2020;6(16). doi:10.1038/s41421-0200156-0

7. Yao X, Ye F, Zhang M, Cui C, Huang B, Niu $\mathrm{P}$, et al. In vitro antiviral activity and projection of optimized dosing design of hydroxychloroquine for the treatment of severe acute respiratory syndrome Coronavirus 2 (SARS-CoV-2). Clin Infect Dis.
2020;71(15):732-739.

doi:10.1093/cid/ciaa237

8. Aktas, A., Tuzun, B., Taskin, A. H., Sayin, K., \& Ataseven, H. (2020). How do arbidol and its analogs inhibit the SARS-CoV2?. Bratislavske lekarske listy, 121(10), 705711.

9. Gao J, Tian Z, Yang X. Breakthrough: Chloroquine phosphate has shown apparent efficacy in treatment of COVID-19 associated pneumonia in clinical studies. Biosci Trends. 2020;14(1):72-73. doi:10.5582/bst.2020.01047

10. Madrid PB, Panchal RG, Warren TK, Shurtleff AC, Endsley AN, Green CE, et al. Evaluation of Ebola Virus Inhibitors for Drug Repurposing. ACS Infect Dis. 2015;1(7):317326. doi:10.1021/acsinfecdis.5b00030

11. Retallack H, Di Lullo E, Arias C, Knopp KA, Laurie MT, Sandoval-Espinosa C, et al. Zika virus cell tropism in the developing human brain and inhibition by azithromycin. Proc Natl Acad Sci U S A. 2016;113(50):14408-14413. doi:10.1073/pnas.1618029113

12. Trac MH, McArthur E, Jandoc R, Dixon SN, Nash DM, Hackam DG, et al. Macrolide antibiotics and the risk of ventricular arrhythmia in older adults. CMAJ. 2016;188(7):E120-E129. doi:10.1503/cmaj.150901

13. Choi Y, Lim HS, Chung D, Choi JG, Yoon D. Risk evaluation of zzithromycin-induced QT prolongation in real-world practice. Biomed Res Int. 2018;2018:1574806. doi:10.1155/2018/1574806

14. Frommeyer G, Fischer C, Ellermann C, Dechering DG, Kochhäuser S, Lange PS, et al. Additive proarrhythmic effect of combined treatment with QT-prolonging agents. Cardiovasc Toxicol. 2018;18(1):84-90. doi:10.1007/s12012-017-9416-0

15. Bakhshaliyev N, Uluganyan M, Enhos A, Karacop E, Ozdemir R. The effect of 5-day course of hydroxychloroquine and azithromycin combination on QT interval in non-ICU COVID19(+) patients. J Electrocardiol. 2020;62:59-64. doi:10.1016/j.jelectrocard.2020.08.008

16. Lu HR, Yan GX, Gallacher DJ. A new biomarker--index of cardiac electrophysiological balance (iCEB)--plays an important role in drug-induced cardiac 
arrhythmias: beyond QT-prolongation and Torsades de Pointes (TdPs). J Pharmacol Toxicol Methods. 2013;68(2):250-259. doi:10.1016/j.vascn.2013.01.003

17. Robyns T, Lu HR, Gallacher DJ, Garweg C, Ector J, Willems R, et al. Evaluation of index of cardio-electrophysiological balance (iCEB) as a new biomarker for the identification of patients at increased arrhythmic risk. Ann Noninvasive Electrocardiol. 2016;21(3):294304. doi:10.1111/anec.12309

18. Wang $X$, Zhang L, Gao C, Zhu J, Yang X. Tpeak-Tend/QT interval predicts ST-segment resolution and major adverse cardiac events in acute ST-segment elevation myocardial infarction patients undergoing percutaneous coronary intervention. Medicine (Baltimore). 2018 Oct;97(43):e12943. doi: 10.1097/MD.0000000000012943. PMID: 30412109 ; PMCID: PMC6221564.

19. Ardahanli, I., \& Celik, M. Comparison of Tp-e interval, QTc interval and Tp-e/QTc ratios between non-diabetic and prediabetic population. Ann Med Res 2020;27(12):311722. DOI: 10.5455/annalsmedres.2020.09.949

20. Nafakhi H, Al-Mosawi AA, Alareedh M, AlNafakh HA. Index of cardiac electrophysiological balance and transmural dispersion of the repolarization index relationships with pericardial fat volume and coronary calcification. Biomark Med. 2018;12(4):321-328. doi:10.2217/bmm-20170187

21. Özdemir L, Sökmen E. Effect of habitual cigarette smoking on the index of cardiac electrophysiological balance in apparently healthy individuals. J Electrocardiol. 2020;59:41-44. doi:10.1016/j.jelectrocard.2020.01.003

22. Hemmeryckx B, Feng Y, Frederix L, Lox M, Trenson S, Vreeken R, et al. Evaluation of cardiac arrhythmic risks using a rabbit model of left ventricular systolic dysfunction. Eur J Pharmacol. 2018;832:145-155. doi:10.1016/j.ejphar.2018.05.026

23. Cipriani A, Zorzi A, Ceccato D, Capone F, Parolin M, Donato F, et al. Arrhythmic profile and 24-hour QT interval variability in COVID19 patients treated with hydroxychloroquine and azithromycin. Int J Cardiol. 2020;316:280284 doi:10.1016/j.ijcard.2020.05.036

24. Wang D, Hu B, Hu C, Zhu F, Liu X, Zhang J, et al. clinical characteristics of 138 hospitalized patients with 2019 Novel Coronavirus-Infected Pneumonia in Wuhan, China. JAMA. 2020;323(11):1061-1069. doi:10.1001/jama.2020.1585 